\title{
Meanings of intrafamily violence experienced in childhood/ adolescence present in the discourses of men
}

\author{
Significados da violência intrafamiliar vivenciada na infância/adolescência presentes nos discursos de homens
}

Significados de la violencia intrafamiliar experimentada en la niñez/adolescencia presentes en los discursos de hombres

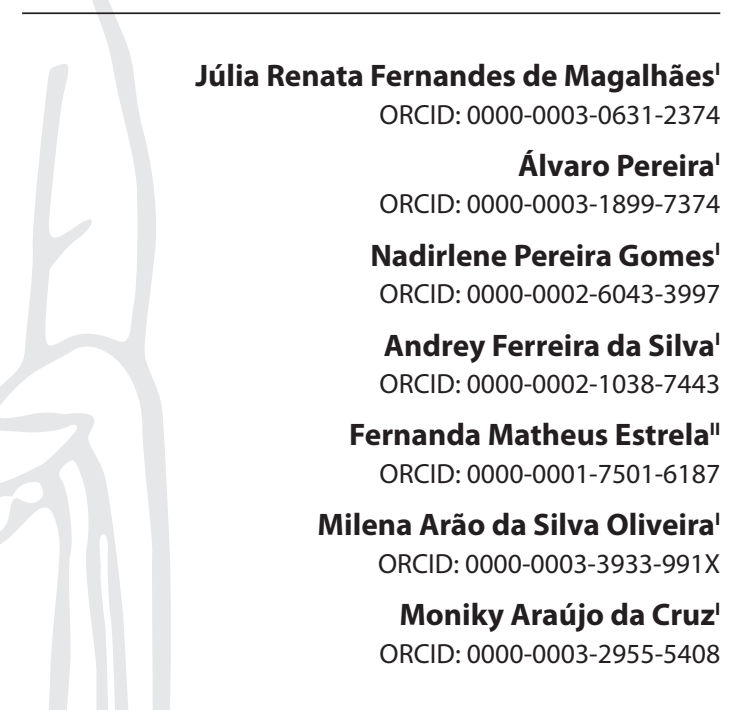

'Universidade Federal da Bahia. Salvador, Bahia, Brazil. "Universidade Estadual de Feira de Santana. Feira de Santana, Bahia, Brazil.

How to cite this article: Magalhães JRF, Pereira A, Gomes NP, Silva AF, Estrela FM, Oliveira MAS, et al. Meanings of intrafamily violence experienced in childhood/ adolescence present in the discourses of men. Rev Bras Enferm. 2021;74(Suppl 3):e20200238. doi: http://dx.doi.org/10.1590/0034-7167-2020-0238

Corresponding author: Julia Renata Fernandes de Magalhães E-mail: julinha_cte@hotmail.com

EDITOR IN CHIEF: Antonio José de Almeida Filho ASSOCIATE EDITOR: Hugo Fernandes

Submission: 07-16-2020

Approval: 09-17-2020

\section{ABSTRACT}

Objective: to unveil the meanings of intrafamily violence experienced in childhood and/or adolescence by men under legal proceedings due to conjugal violence. Method: a qualitative research, based on Thematic Oral History and supported by Symbolic Interactionism. Participants were men under legal proceedings due to domestic violence who had experienced or witnessed intrafamily violence in childhood and/or adolescence. Results: the speeches revealed that the intrafamily violence experienced in childhood and/or adolescence was signified as an educational method. The aggressions committed by parents were only perceived as acts of violence in situations considered extreme, such as in cases of using a firearm, handcuffs, and rope. Final considerations: considering that the meanings direct human conduct and that they are subject to modification depending on social interactions built throughout life, it is believed that educational strategies that encourage the redefinition of violence can be effective in facing this problem.

Descriptors: Violence; Men; Symbolic Interactionism; Family Relations; Nursing.

\section{RESUMO}

Objetivo: desvelar os significados da violência intrafamiliar vivenciada na infância e/ou adolescência por homens em processo jurídico por violência conjugal. Método: pesquisa qualitativa, fundamentada no método da História Oral Temática e respaldada pelo referencial teórico do Interacionismo Simbólico. Os participantes foram homens em processo jurídico por violência conjugal que tinham experienciado ou testemunhado violência intrafamiliar na infância e/ou adolescência. Resultados: os discursos revelaram que a violência intrafamiliar vivenciada na infância e/ou adolescência foi significada enquanto método educativo. As agressões cometidas pelos pais somente foram percebidas como atos de violência em situações consideradas extremas, como em casos de uso de arma de fogo, algemas e corda. Considerações finais: considerando que os significados direcionam as condutas humanas e que os mesmos são passíveis de modificação a depender das interações sociais construídas ao longo da vida, acredita-se que estratégias educativas que estimulem a ressignificação da violência possam ser eficazes no enfrentamento desse agravo.

Descritores: Violência; Homens; Interacionismo Simbólico; Relações Familiares; Enfermagem.

\section{RESUMEN}

Objetivo: develar los significados de la violencia intrafamiliar vivida en la infancia y/o adolescencia por hombres en procesos judiciales por violencia conyugal. Método: investigación cualitativa, basada en el método de Historia Oral Temática y sustentada en el marco teórico del Interaccionismo Simbólico. Los participantes fueron hombres en procesos judiciales por violencia intrafamiliar que habían experimentado o presenciado violencia intrafamiliar en la niñez y/o adolescencia. Resultados: los discursos revelaron que la violencia intrafamiliar vivida en la niñez y/o adolescencia se significó como método educativo. Las agresiones cometidas por los padres solo fueron percibidas como actos de violencia en situaciones consideradas extremas, como en los casos de uso de arma de fuego, esposas y cuerdas. Consideraciones finales: considerando que los significados dirigen la conducta humana y que están sujetos a modificación en función de las interacciones sociales construidas a lo largo de la vida, se cree que las estrategias educativas que incentiven la redefinición de la violencia pueden ser efectivas para enfrentar esta problemática.

Descriptores: Violencia; Hombres; Interaccionismo Simbólico; Relaciones Familiares; Enfermería. 


\section{INTRODUCTION}

Intrafamily violence against children and adolescents is a historical phenomenon that has perpetuated throughout the generations, being responsible for the illness and death of thousands of children worldwide. It can be understood as the manifestation of any and all forms of violence, whether physical, sexual, emotional, as well as the abandonment, neglect or exploitation committed by a family member, even without blood ties, against people aged or under nineteen years ${ }^{(1)}$.

This is considered an important public health problem. An international survey shows that approximately 227 children and adolescents die daily from intrafamily violence ${ }^{(1)}$. Brazil presents itself in a similar situation, as evidenced by the statistics of 2015, by revealing that more than 10,000 children and adolescents were killed by violent causes in that period, with most of the cases having authors from the family circle and coexistence of the victims ${ }^{(2)}$. Among the offenders, parents and stepfathers stand out for being the main responsible for childhood and adolescence violence ${ }^{(3)}$.

Although the numbers are alarming and reflect the current context, this is not a recent problem. Several studies show that violent behavior has been part of the daily life of children and adolescents, since the dawn of humanity, and has always been treated by society as something natural ${ }^{(4)}$. This trivialization of childhood and/or adolescence violence, in turn, is linked to the thought that the education of children should be conducted through punitive measures, including through physical punishment ${ }^{(5)}$.

However, there is no consensus on such practices. The lack of definition of what is considered acceptable or excessive in the family's attitude in the educational process often causes relationships of affection and power between parents and children to be confused $^{(6)}$. In order precisely to establish limits and guarantee the safety and integrity of children and adolescents, in 2014, Law 13,010 , popularly known as "Spanking" Law, was sanctioned. This prevents the use of physical punishment or cruel or degrading treatment based on humiliation, serious threat or ridicule, as well as defends education based on dialogue and affection ${ }^{(7)}$.

The aforementioned legislation recognizes that family interactions based on violence significantly compromise the development of children and adolescents. Thus, it is believed that their exposure to abuse in the family can influence their perception of this phenomenon, legitimizing it as an appropriate way to resolve conflicts. This happens because childhood and adolescence are the periods when the personality is in the process of formation ${ }^{(8)}$.

In the case of boys, they tend to copy behaviors adopted by the male reference figure, usually represented by the father ${ }^{(9)}$. Under this view, it is thought that children of offending parents can naturalize such conduct, understanding it as inherent to the male, in order to also become violent adults in their interpersonal relationships ${ }^{(10)}$. A study conducted with married Bangladeshi men showed that those who lived in homes permeated by violence were more likely to commit aggression against their intimate partners ${ }^{(11)}$. In line with this result, a Brazilian study also showed a correlation between conjugal violence and the experiences of aggression in childhood and/or adolescence, since men perceive themselves reproducing in conjugality the same paternal attitudes ${ }^{(12)}$.
This reproduction of violence can be understood from the theoretical framework of symbolic interactionism (SI), which starts from the premise that human behavior emerges from the way people interpret and signify their experiences ${ }^{(13)}$. Thus, it is believed that the meanings attributed by men to their violent experiences in childhood and adolescence direct their own conduct, including in their marital relationship.

In this sense, considering that the meanings are dynamic and can be modified depending on the interactions and reflections developed throughout life ${ }^{(13)}$, the question is: how men under legal proceeding due to conjugal violence mean the intrafamily violence experienced in childhood and/or adolescence?

\section{OBJECTIVE}

To unveil the meanings of intrafamily violence experienced in childhood and/or adolescence by men under legal proceedings due to conjugal violence.

\section{METHODS}

\section{Ethical aspects}

All participants were informed about the relevance and objectives of the study, the right to participate or not in the research, to withdraw at any time, as well as information anonymity and confidentiality. The men were identified using alphanumeric coding (M1, M2, ... M13). Those who agreed to participate signed the Informed Consent Form. These and other ethical issues aimed to meet what is advocated by Resolution 466/12 of the Brazilian National Health Council (Conselho Nacional de Saúde). It should be noted that this study was approved by the Research Ethics Committee of Universidade Federal da Bahia School of Nursing (CEPEE/UFBA).

\section{Theoretical-methodological framework}

Thematic Oral History proposes to deepen aspects of a given reality from other individuals' experiences ${ }^{(14)}$. SI, in turn, makes it possible to understand the way people signify the objects and other subjects with whom they interact and how this process of interpretation leads daily behaviors ${ }^{(15)}$. Thus, it is assumed that the meanings attributed by men to their experiences in childhood/ adolescence guide the way they act and react in their daily lives, including in their marital relationships.

\section{Methodological procedures}

In order to get closer to the collaborators, all researchers involved developed Reflective Groups with Men (RGM). It is a strategy for the prevention and confrontation of conjugal violence promoted by the Study Group "Violence, Health and Quality of Life" at UFBA School of Nursing, in line with what is proposed in Law 11.340/06, known as Maria da Penha Law.

Four rounds of meetings were held, with a total of 44 men. Through the dynamics carried out, it was possible to establish a closer contact with the participants, which made it possible to know their life experiences and recognize those with a history of 
intrafamily violence in childhood and adolescence. At the end of the meetings, members who met the inclusion criteria were contacted by phone and invited to participate in the study. Of these, 13 signaled in a positive way about their participation in the referred research, however, in the sixth interview, it was considered that the data collected already allowed analysis and deepening of the object under study, not being necessary to select new participants.

\section{Type of study}

This is a qualitative research, based on the Thematic Oral History method and supported by the SI theoretical framework. The survey complied with the Consolidated criteria for reporting qualitative research (COREQ).

\section{Study setting}

Data collection took place from April to July 2018 by retrieving participants'Thematic Oral History, with the Second Domestic Peace Court, located in the city of Salvador, Bahia, Brazil, as a study setting.

\section{Data source}

Participants were six men legally proceeding due to domestic violence and who had experienced or witnessed intrafamily violence in childhood and/or adolescence. All of them were emotionally stable to participate in data collection, according to assessment carried out by a psychologist linked to the Court, with no need for exclusion. It should be noted that the number of participants was not previously defined, since oral history prioritizes the deepening of the narratives due to the number of participants.

\section{Data collection and organization}

As a technique, we used the interview guided by a semistructured script prepared by the researchers, contemplating sociodemographic aspects for characterization of subjects (age, religion, race/color, education, and family income) and the following guiding question: tell me, how was your relationship with your family in childhood? It is noteworthy that the dialogue was established through simple, clear and direct language, as presumed in oral history.

The interviews were conducted individually, with an average duration of two hours and thirty minutes, in a place previously agreed with participants. All recorded oral content, upon authorization, was transcribed in full with support of Microsoft Word. Then, textualization was carried out, a phase in which the discourse is organized in the first person singular, excluding unnecessary elements, and transcreation, the logical organization of the text ${ }^{(14)}$.

\section{Data analysis}

All written material was checked by the participants, who signed the letter of rights session. After authorization for using textual corpus, the narratives were systematized based on Thematic Content Analysis, comprising pre-analysis, material exploration, treatment of results and interpretation ${ }^{(16)}$. This process was made possible by the NVIVO 11 software, created to favor the organization of qualitative data. After exhaustive reading of the content, the speeches related to each axis theme were identified, emerging the analytical categories, which were interpreted in the light of SI.

\section{RESULTS}

Six men were interviewed under legal proceeding due to conjugal violence at the Second Domestic Peace Court in the municipality of Salvador, Bahia, Brazil. They were aged between 27 and 41 years old, declared themselves black (four mixed-ethnicity and two black), three were Catholics, two were Evangelicals and one was Spiritualist. Regarding marital status, half of participants reported being single and the other married. As for education, only one reported having completed higher education, three had completed high school and two had incomplete elementary school. The income varied between one thousand and one hundred reais to ten thousand reais. All reported the disruption of the marital relationship with the partner who reported the violence.

In relation to oral history about childhood and adolescence, the male speeches referred to an experience of intrafamily violence expressed through physical aggressions, curses and threats. Despite this context, most respondents did not perceive themselves as victims of violence, meaning it as an educational tool used by parents in a natural, relevant and necessary way. The meaning of violence as inappropriate conduct only emerged when the interaction between father and son was marked by aggressive parenting practices considered extreme, such as conduct such as handcuffing, stoning, tying and shooting with a firearm.

Chart 1 shows the synthesis of the oral history of intrafamily violence experienced in childhood and adolescence, as well as the meanings that men attribute to this violence.

Chart 1 - Synthesis of the oral history of intrafamily violence experienced in childhood and adolescence and meanings by men to this violence

\begin{tabular}{|c|l|l|}
\hline Participant & Oral history of intrafamily violence in childhood/adolescence & \multicolumn{1}{c|}{ Meaning of intrafamily violence in childhood/adolescence } \\
\hline M1 & $\begin{array}{l}\text { My father beat me up with a belt. He hit me so hard that my } \\
\text { mother needed to intervene. }\end{array}$ & $\begin{array}{l}\text { I do not consider that I have suffered violence. I have no doubt that I } \\
\text { really needed to be beaten to form the man I am today because I was so } \\
\text { naughty and that was a way of educating myself. }\end{array}$ \\
\hline M2 & $\begin{array}{l}\text { My father locked everything up and said that everyone was going } \\
\text { to be beaten and nobody could say anything. [...] he beats us, } \\
\text { beaten a strap, beaten on the back, slapped in the ear, broke us. }\end{array}$ & $\begin{array}{l}\text { There was never violence inside my house. My father beat me and my brothers } \\
\text { when my mother complained about us. This was a way of educating, so much } \\
\text { so that for people my age it is acceptable to take corrections. }\end{array}$ \\
\hline M3 & $\begin{array}{l}\text { My older brother, who raised me, beat me with a paddle. } \\
\text { Idon't think that I suffered violence in my childhood. He beat me when he } \\
\text { obey my mother, didn't take the garbage out of the house. [...] I felt guilty } \\
\text { when he hit me because I knew I was wrong and deserved to be beaten. }\end{array}$ \\
\hline
\end{tabular}


Chart 1 (concluded)

\begin{tabular}{|c|l|l|}
\hline Participant & Oral history of intrafamily violence in childhood/adolescence & \multicolumn{1}{c|}{ Meaning of intrafamily violence in childhood/adolescence } \\
\hline M4 & My father beat us with punches, kicks. & $\begin{array}{l}\text { I think he beat me not to rape me, but because he wanted to teach me } \\
\text { what was right. The other day, I came and asked for forgiveness and to say } \\
\text { I wouldn't do it again, but I always did. }\end{array}$ \\
\hline M5 & $\begin{array}{l}\text { My father mistreated, offended and cursed us. He beat me } \\
\text { and my brothers a lot and it wasn't just slap. }\end{array}$ & $\begin{array}{l}\text { My father did not know how to charge us properly and ended up being } \\
\text { violent towards us. He did these things because we used to work a lot, } \\
\text { mainly to study. }\end{array}$ \\
\hline M6 & $\begin{array}{l}\text { My father was always aggressive, authoritarian. He } \\
\text { threatened to hit me with a stick if I missed the text. He beat } \\
\text { me, threw stone, handcuffed me, tied me up, put me and } \\
\text { my brothers sitting on a couch, lay on another and started } \\
\text { shooting over our heads. }\end{array}$ & $\begin{array}{l}\text { What I experienced in my childhood was certainly violence. Since I was } \\
\text { a child, I got ready, giving my father reasons to hit me, but not to reach } \\
\text { the extreme as he did. Any complaint he received from me was already a } \\
\text { reason for the attacks. }\end{array}$ \\
\hline
\end{tabular}

\section{DISCUSSION}

The oral history of men who respond legally for conjugal violence revealed the experience of a childhood and adolescence permeated by intrafamily violence. This was expressed, above all, through physical and psychological aggressions, manifested by the practice and/or threat of slaps, kicks, punches, use of blunt objects and even a firearm. The experience of domestic violence in childhood and adolescence was also evidenced in a survey carried out in the United Kingdom with $\mathbf{4 0 0}$ men in criminal proceedings for violence against women, who reported having been assaulted through the use of belts, broomsticks and weapons, in addition to suffering threats, curses and humiliations ${ }^{(17)}$.

Although all interviewees describe family contexts permeated by violence, the meanings of such experiences were expressed in a different way based on the subjective and private interactions and interpretations of each one, just as SI supposes ${ }^{(13)}$. Part of the narratives draws attention due to the lack of male recognition of their experiences of physical and psychological aggression in childhood and adolescence as violent practices. These symbolize aggressive fatherly conduct as an educational method, characterizing them as necessary, fair and acceptable. In line with our study, research conducted with adolescents in Palestine also shows that they believe they deserve to receive violent punishments and that punitive forms of education represent a right of parents, who have unquestionable authority ${ }^{(18)}$.

Since the dawn of humanity, child rearing has been shaped according to patriarchal precepts. Parents, represented as holders of the absolute authority and principally responsible for supporting the family, have always had social permission to exercise their power over their children, including through physical and psychological punishment, understood as care actions ${ }^{(19)}$. This model of interaction between parents and children has become so ingrained in the popular imagination that, despite the fact that the person has not been educated by violent means, it is possible that it means such a method as legitimate and appropriate, as evidenced by a study carried out in New Zealand ${ }^{(20)}$.

The participants' oral history reveals the perception that paternal coercion represents a reaction to their children's inappropriate behaviors, including disobedience and lack of commitment to studies. Corroborating, the scientific literature also points out the precipitating elements of the violent act, such as the child's crying, tantrum or indiscipline or even the rebelliousness and irritability of the adolescents, these being considered stressful factors for parents or guardians ${ }^{(21-23)}$. Studies suggest that family offenders tend to blame children and adolescents for their own emotional lack of control and impatience ${ }^{(24)}$.

While parents are encouraged, and, in a way, even socially charged to exercise their authority over their children through violent punishments, little is said about peaceful methods of education, especially through dialogue. Adults generally justify aggression against children as an educational form, but it is necessary to reflect on whether such actions are really guided by their pedagogical character or whether it is a manifestation of lack of control, tantrums and anger in the face of their children's indiscipline.

This model of interaction between parents and children based on violence can be interpreted based on the concept of Self, defined by SI The "me" reflects, therefore, the cultural and social construction imbued with the conception that punishments are educational means as a social process within the individual, involving two distinct phases: the "me" and the "me". The "I" is the individual's impulsive and unpredictable tendency to react to the attitudes of others ${ }^{(25)}$. It is as if the "I", in an impulsive and momentary way, directs parents to act violently before behaviors considered inappropriate by their children. The "me", in turn, refers to the series of organized and self-conscious attitudes that the individual adopts ${ }^{(26)}$. The "me" reflects, therefore, the cultural and social construction imbued with the conception that punishments are educational means.

Regardless the motivation for hitting, whether due to fury or educational intent, several studies prove the damage caused by using physical and psychological punishment in the development of children and adolescents, which can even affect adult life. Considering that a child's learning is related to examples he or she receives, it is believed that using aggressive punishments teaches him or her that violence can be a resource for conflict resolution, so that as adults, they will reproduce this pattern of relationship ${ }^{(27)}$. This reproduction of violence can be understood from the conception of a social act, defined by SI as an individual's practice of putting himself in the shoes of another person, in this case, of the offender father, identifying with his behaviors and incorporating them in their own actions ${ }^{(13)}$.

The speeches also point out that most of the men interviewed symbolized the violence experienced in childhood and adolescence in a naturalized way, except when it was expressed in a way considered extreme, as in the case where the father used handcuffs, rope, stick and even a firearm to commit aggressions. Corroborating, a study points out that expressions of a physical nature are only recognized as more serious when they cause 
damage to health, such as abrasions, bruises, lacerations, burns, head trauma and even death ${ }^{(19)}$.

This significance of violence on the part of men only in extreme cases is worrying, since violent conduct considered more subtle can become tolerable and commonplace. Furthermore, taking into account the precept of SI that says that people's actions are responses not only to the acts of others, but also to their possible intentions ${ }^{(13)}$, it is inferred that boys who were raised by violent means and symbolize the intention of their parents' conduct as a form of correction and care, as adults, may also adopt violent behavior against their partners and children, under the same justification. A study carried out in Minas Gerais based on focus groups with men points out precisely the male perception that the violence committed against women represents a punishment for their acts and attitudes ${ }^{(28)}$.

Considering the complexity of intrafamily violence against children and adolescents and the impacts it can have on health and society, Brazilian law itself, through Law 13.010/2014, proposes the training and continuing education of health professionals, education and social assistance and the other agents that work with children and adolescents to prevent, identify and face all forms of violence. The law determines the inclusion of this theme in public policies since prenatal care, carrying out educational and reflective activities with parents and guardians who can provide alternatives to the use of physical punishment in the educational process, in addition to promoting intersectoral spaces for the elaboration of joint action plans focused on families in situations of violence ${ }^{(27)}$.

\section{Study limitations}

Data indicate the importance of research aimed at investigating the relationship between the violence practiced and the meaning attributed to their own violent experiences. This is considered a limitation of this study.

\section{Contributions to nursing}

Nurses are in a strategic position to develop actions to prevent and deal with intrafamily violence, mainly through the work developed in Primary Care through the Family Health Strategy (FHS), which requires greater proximity and monitoring of families in their care. territorial context. Among the government strategies to confront intrafamily violence against children and adolescents linked to FHS, Health at School Program (PSE - Programa Saúde na Escola) stands out. PSE proposes an intersectoral partnership between health and education to face the vulnerabilities that affect the public childhood and/or adolescence, with education and health activities as the focus of its interventions ${ }^{(29)}$.

In this sense, based on SI premise that behavior is guided by the way people interpret and signify their experiences, it is believed that such educational activities should encourage children and adolescents to reflect on the meaning of violent experiences, as well as the impacts that they can trigger. The construction of these meanings, in turn, is dynamic and influenced by individual values and interpersonal interactions built throughout life ${ }^{(13)}$. Hence the importance of professionals working in the fields of education and health, especially nurses, to build positive interactions with children and adolescents, in order to favor the process of reframing their stories, which makes them less likely to be involved in situations of violence.

\section{FINAL CONSIDERATIONS}

The oral history of men under legal proceeding due to conjugal violence reveals that intrafamily violence experienced in childhood and/or adolescence was meant as an educational method. The physical and psychological aggressions committed by the parents were considered, in general, fair and necessary, being perceived as acts of violence only in situations considered extreme, such as in cases of use of firearms, handcuffs and rope.

With parents, it is possible to encourage reflection about the risk-benefit of educational practices based on violence, questioning whether they are really guided by pedagogical intention or as a manifestation of power and domination over their children. With children and adolescents, it is important to address the damage that violence can cause and the possibilities of ways to avoid it. With parents, it is possible to encourage reflection about the riskbenefit of educational practices based on violence, questioning whether they are really guided by pedagogical intention or as a manifestation of power and domination over their children. With children and adolescents, it is important to address the damage that violence can cause and the possibilities of ways to avoid it.

With parents, it is possible to encourage reflection about the risk-benefit of educational practices based on violence, questioning whether they are really guided by pedagogical intention or as a manifestation of power and domination over their children. With children and adolescents, it is important to address the damage that violence can cause and the possibilities of ways to avoid it.

\section{REFERENCES}

1. World Health Organization (WHO). Strengthening the role of the health system in addressing violence, in particular against women and girls, and against children [Internet]. Geneva: Sixty-Seventh World Health Assembly Resolution, 2014 [cited 2020 Apr 04]. Available from: http://apps.who.int/gb/ebwha/pdf_files/WHA67/A67_R15-en.pdf?ua=1

2. Associação Brasileira dos Fabricantes de Brinquedos. Cenário da infância e adolescência no Brasil [Internet]. São Paulo: ABRINQ; 2017 [cited $2020 \mathrm{Apr}$ 01]. 60 p. Available from: http://www.chegadetrabalhoinfantil.org.br/wp-content/uploads/2017/03/Cenario-2017-PDF.pdf

3. Moreschi MT. Violência contra crianças e adolescentes: análise de cenários e propostas de políticas públicas [Internet]. Brasília: Ministério dos Direitos Humanos; 2018 [cited 2020 Aug 26]. 494 p. Available from: https://www.gov.br/mdh/pt-br/centrais-de-conteudo/crianca-eadolescente/violencia-contra-criancas-e-adolescentes-analise-de-cenarios-e-propostas-de-politicas-publicas-2.pdf

4. Silva Jr GB, Rolim ACA, Moreira GAR, Corrêa CRS, Vieira LJES. Identificação e notificação de maus-tratos em crianças e adolescentes por médicos de família no Ceará. Trab Educ Saúde. 2017;15(2):469-84. doi: 10.1590/1981-7746-sol00058 
5. Magalhães JRF, Gomes NP, Mota RS, Campos LM, Camargo CL, Andrade SR. Intra-family violence: experiences and perceptions of adolescents. Esc Anna Nery. 2017;21(1). doi: 10.5935/1414-8145.20170003

6. Essy DB. A evolução histórica da violência contra a mulher no cenário brasileiro: do patriarcado à busca pela efetivação dos direitos humanos femininos [Internet]. Brasília-DF: Conteúdo Jurídico; 2017 [cited 2020 Apr 01]. Available from: https://www.conteudojuridico. com.br/consulta/Artigos/50534/a-evolucao-historica-da-violencia-contra-a-mulher-no-cenario-brasileiro-do-patriarcado-a-busca-pelaefetivacao-dos-direitos-humanos-femininos

7. Presidência da República (BR). Lei no 13.010, de 26 de junho de 2014. Altera a Lei no 8.069, de 13 de julho de 1990 (Estatuto da Criança e do Adolescente), para estabelecer o direito da criança e do adolescente de serem educados e cuidados sem o uso de castigos físicos ou de tratamento cruel ou degradante, e altera a Lei no 9.394, de 20 de dezembro de 1996 [Internet]. Brasília: Diário Oficial da União; 2014[cited 2020 Apr 01]. Available from: http://www.planalto.gov.br/ccivil_03/_Ato2011-2014/2014/Lei/L13010.htm

8. Sutin AR, Terracciano A. Mother and child personality traits associated with common feeding strategies and child body mass index. Appetite. 2018;125:295-301. doi: 10.1016/j.appet.2018.02.009

9. Marasca AR, Razera J, Pereira HJR, Falcke D. Marital physical violence suffered and committed by men: repeating family patterns? Psico-USF. 2017;22(1):99-108. doi: 10.1590/1413-82712017220109

10. Bates EA. "No one would ever believe me": an exploration of the impact of intimate partner violence victimization on men. Psychol Men Masculinities. 2019. doi: 10.1037/men0000206

11. Islam MJ, Mazerolle P, Broidy L, Baird K. Exploring the prevalence and correlates associated with intimate partner violence during pregnancy in Bangladesh. J Interpers Violence. 2017;088626051773002. doi: 10.1177/0886260517730029

12. Lírio JGS, Gomes NP, Paixão GPN, Pereira Á, Magalhães JRF, Cruz MA, et al. Intrafamilial abuse in the childhood of men criminally prosecuted for domestic violence. Acta Paul Enferm. 2018;31(4):423-9. doi: 10.1590/1982-0194201800059

13. Blumer H. Symbolic interactionism: perspective and method. Englewood Cliffs [NJ]: Prentice Hall; 1969.

14. Meihy J, Holanda F. História oral: como fazer, como pensar. 2a. Contexto; 2014.

15. Correia AS. Interacionismo simbólico: raízes, críticas e perspectivas atuais. Rev Bras Hist Ciênc Soc [Internet]. 2017 [cited 2020 Jun 20];9(17):176-200. Available from: https://periodicos.furg.br/rbhcs/article/view/10661/pdf

16. Bardin L. Análise de Conteúdo. São Paulo: Edições 70; 2011.

17. Theobald D, Farrington DP, Coid JW, Piquero AR. Are male perpetrators of intimate partner violence different from convicted violent offenders? examination of psychopathic traits and life success in males from a community survey. J Interpers Violence. 2016;31(9):1687-718. doi: $10.1177 / 0886260515569061$

18. Ali-Saleh Darawshy N, Haj-Yahia MM. Palestinian adolescents' exposure to community violence and internalizing and externalizing symptoms: parental factors as mediators. Child Youth Serv Rev. 2018;95:397-406. doi: 10.1016/j.childyouth.2018.11.017

19. Moreno-Roldán MR, Agudelo-Bedoya ME, Alzate-Pulgarín V. Voces a escuchar en el cuidado: ¿qué dicen los niños y las niñas? RLCSNJ [Internet]. 2017 [cited 2020 Apr 01];16 (1). Available from: http://revistaumanizales.cinde.org.co/rlcsnj/index.php/Revista-Latinoamericana/article/view/3099

20. D'Souza AJ, Russell M, Wood B, Signal L, Elder D. Attitudes to physical punishment of children are changing. Arch Dis Child. 2016;101(8):6903. doi: 10.1136/archdischild-2015-310119

21. Ferreira CLS, Côrtes MCJW, Gontijo ED. Promoção dos direitos da criança e prevenção de maus tratos infantis. Cienc Saúde Colet. 2019;24(11):3997-4008. doi: 10.1590/1413-812320182411.04352018

22. Lin X, Li L, Chi P, Wang Z, Heath MA, Du H, et al. Child maltreatment and interpersonal relationship among Chinese children with oppositional defiant disorder. Child Abuse Negl. 2016;51:192-202. doi: 10.1016/j.chiabu.2015.10.013

23. Ioane J, Lambie I, Percival T. A comparison of pacific, māori, and european violent youth offenders in New Zealand. Int J Offender Ther Comp Criminol. 2016;60(6):657-74. doi: 10.1177/0306624X14560725

24. Zhang L, Cai C, Wang Z, Tao M, Liu X, Craig W. Adolescent-to-Mother psychological aggression: the role of father violence and maternal parenting style. Child Abuse Negl. 2019;98:104229. doi: 10.1016/j.chiabu.2019.104229

25. Dupas G, Oliveira I, Costa TNA. A importância do interacionismo simbólico na prática de enfermagem. Rev Esc Enferm USP. 1997;31(2):21926. doi: 10.1590/S0080-62341997000200004

26. Caria T, Ramos M. Uma abordagem interacional dos saberes e das culturas profissionais. Rev Trab Neces. 2018;16(30). doi: 10.22409/tn.16i30. p10085

27. Passos TA. Educação sem violência: um direito de crianças e adolescentes [Internet]. Brasília: Ministério dos Direitos Humanos, 2018 [cited 2020 Apr 01]. Available from: https://www.mdh.gov.br/biblioteca/crianca-e-adolescente/educacao-sem-violencia-um-direito-de-criancase-adolescentes.pdf

28. Carlos CM, Melo EM, Benedito MF, Canazart JA, Souza AKE, Melo VH. Análise das percepções e dos cuidados à mulher em situação de violência pelos profissionais da rede de atendimento local em um território prioritário brasileiro. Rev Med Minas Gerais [Internet]. 2016[cited 2020 Apr 01];26(Supl 8):S46-S50. Available from: http://rmmg.org/artigo/detalhes/2121

29. Presidência da República (BR). Decreto n. 6.286, de 5 de dezembro de 2007. Institui o Programa Saúde na Escola (PSE), e dá outras providências [Internet]. Diário Oficial da União, Brasília, DF, p. 2, 5 dezembro de 2007 [cited 2020 Apr 01]. Available from: http://www. planalto.gov.br/ccivil_03/_ato2007-2010/2007/decreto/d6286.htm 